\title{
STUDI DESKRIPTIF MENGENAI PARENTING SELF-EFFICACY PADA IBU YANG MEMILIKI ANAK DENGAN AUTISM SPECTRUM DISORDER
}

\author{
Nadia Ayu Larasati, Laila Qodariah, dan Poeti Joefiani \\ Fakultas Psikologi, Universitas Padjadjaran \\ Jl. Raya Bandung Sumedang Km 21, Kabupaten Sumedang, Jawa Barat, 45363 \\ E-mail: nadiaayulrst@gmail.com
}

\begin{abstract}
ABSTRAK
Kehadiran anak berkebutuhan khusus, khususnya anak dengan gangguan autism spectrum disorder, dapat memberikan kesulitan-kesulitan kepada ibu dalam masa pengasuhan. Kesulitan tersebut juga memberikan dampak kepada keadaan psikologis ibu. Para ibu memerlukan sebuah keyakinan atas kemampuan dirinya dalam mengasuh anak agar dapat memberikan sebuah pengasuhan yang positif. Keyakinan atas kemampuan dirinya dalam mengasuh ini dikenal sebagai istilah parenting self-efficacy. Parenting self-efficacy merupakan penilaian orang tua mengenai kompetensinya dalam melakukan peran sebagai orang tua. Penelitian ini bertujuan untuk memberikan gambaran umum mengenai tingkat parenting self-efficacy pada ibu yang memiliki anak dengan ASD. Penelitian ini menggunakan metode penelitian deskriptif menggunakan alat ukur Self-Efficacy for Parenting Task Index berdasarkan teori parenting self-efficacy untuk ibu yang memiliki anak usia 5-12 tahun, yang terdiri dari 36 pertanyaan. Kuesioner ini memiliki reliabilitas sebesar 0,875, yang menunjukkan bahwa alat ukur ini dapat diandalkan. Partisipan penelitian ini adalah 34 orang ibu yang memiliki anak dengan ASD berusia 5-12 tahun. Hasil penelitian menunjukkan bahwa $85 \%$ ibu yang memiliki anak ASD usia 5-12 tahun memiliki tingkat parenting selfefficacy yang tinggi. Hal ini menunjukkan bahwa sebagian besar ibu memiliki perilaku pengasuhan yang positif, dengan lingkungan yang adaptif, menstimulasi, dan mendukung. Dimensi discipline memiliki nilai rata-rata paling rendah di antara keempat dimensi lainnya, yang berarti sebagian besar ibu merasa kurang yakin akan kemampuannya dalam menetapkan aturan dan disiplin bagi anak. Berdasarkan hasil penelitian, didapatkan bahwa ibu yang terlibat dalam komunitas memiliki tingkat parenting self-efficacy yang lebih tinggi, namun masih diperlukan penelitian lebih lanjut mengenai peranan komunitas terhadap tingkat parenting self-efficacy.
\end{abstract}

Kata kunci: parenting self-efficacy; autism spectrum disorder; anak usia 5-12 tahun

\section{DESCRIPTIVE STUDY OF PARENTING SELF-EFFICACY IN MOTHERS WHO HAVE CHILDREN WITH AUTISM SPECTRUM DISORDER}

\begin{abstract}
The presence of children with special needs, especially children with autism spectrum disorder, may give difficulties for mothers in the nurturance period. These difficulties have impacts on the psychological state of the mother. The mother needs to believe in their caregiving. Confidence in parents' ability to nurture is known as parenting selfefficacy. Parenting self-efficacy is the assessment of parents' competence in performing the role of parent. This study aimed to provide an overview of the level of parenting self-efficacy in mothers who have children with ASD. This research used the descriptive research method used "Self-Efficacy for Parenting Task Index" as a measuring instrument, based on the theory of parenting self-efficacy for mothers who have children aged 5-12 years, consisted of 36 questions. The reliability score of this questionnaire was 0.875 , which shows that this measuring instrument is reliable. Participants in this study were 34 mothers who had children with ASD aged 5-12 years. Research showed that $85 \%$ of participants had a high level of parenting self-efficacy. This showed that most mothers had positive parenting behaviors. The dimension of discipline had the lowest average value, which means most mothers, in particular, feel less sure of their ability to set rules and discipline for children. Based on the results of the study, it was found that mothers who were involved in the community had a higher level of parenting self-efficacy, but further research is still needed on the role of the community on the level of parenting self-efficacy.
\end{abstract}

Keywords: parenting self-efficacy; autism spectrum disorder; children aged 5-12 years 


\section{PENDAHULUAN}

Setiap orang tua pastinya mengharapkan kehadiran anak yang terlahir sempurna dan sehat, baik secara fisik maupun psikis (Rachmawati \& Masykur, 2017). Namun, pada kenyataannya tidak semua anak terlahir sempurna, ada pula anak yang terlahir memiliki kebutuhan khusus (Ghoniyah \& Savira, 2015). Salah satu jenis kebutuhan khusus yang dimiliki anak adalah autism spectrum disorder, selanjutnya disebut ASD. Autism spectrum disorder (ASD) merupakan gangguan neurodevelopmental yang ditandai dengan kurangnya kemampuan komunikasi dan interaksi sosial, serta adanya pola perilaku yang bersifat repetitif atau berulang (American Psychiatric Association, 2013). Umumnya, gejala ASD muncul ketika anak berada di masa early childhood, namun pada masa tersebut masih sulit untuk diidentifikasi atau didiagnosis (National Institute of Mental Health, 2016; Priyatna, 2010). Anak dengan ASD lebih mudah diidentifikasi gejalanya dan didiagnosis ketika anak mulai memasuki usia sekolah, atau masa middle and late childhood (National Institute of Mental Health, 2016; Priyatna, 2010; Santrock, 2014).

Pada masa middle and late childhood, anak seharusnya sudah mulai berhubungan dengan lingkungan sekolah dan mulai membangun relasi dengan teman seusianya (Coleman \& Karraker, 2000). Pada anak dengan ASD, proses membangun hubungan dengan lingkungan dan teman seusianya mengalami hambatan karena adanya gangguan pada perkembangan psikososial anak (Desiningrum, 2016; National Institute of Mental Health, 2016; Priyatna, 2010). Hambatan yang muncul pada anak dengan ASD akan menjadi tantangan bagi orang tua, terutama bagi ibu (Valentia, Sani, \& Anggreany, 2017). Ibu merupakan pengasuh atau caregiver utama bagi anak karena ibu memiliki keterlibatan yang kuat pada aktivitas anak sehari-hari (Indrasari \& Affiani, 2018). Ibu yang memiliki anak normal berusia 5-12 tahun sedang berada dalam posisi yang unik karena ibu harus membantu anak menghadapi tantangan perkembangan anak, terutama dalam konteks sekolah (Coleman \& Karraker, 2000). Posisi unik ini membuat ibu yang memiliki anak dengan ASD mendapatkan kesulitan yang lebih besar karena selain ibu harus membantu anak memenuhi tugas perkembangannya, ibu juga harus menghadapi gejala autistik anak, yang tentunya akan membuat proses pengasuhan menjadi lebih sulit (Listiyaningsih \& Dewayani, 2009; Widiastuti, 2014).

Parenting self-efficacy berangkat dari teori self-efficacy Bandura yang dikembangkan dalam ranah parenting (Coleman \& Karraker, 1997). Parenting self-efficacy merupakan estimasi kompetensi referensi diri orang tua tentang kemampuan mereka untuk secara positif memengaruhi perilaku dan perkembangan anak-anak mereka (Coleman \& Karraker, 2000). Parenting self-efficacy dapat diukur melalui lima dimensi, yaitu: a) kemampuan dalam memfasilitasi pencapaian anak di sekolah (achievement), b) kemampuan mendukung kebutuhan rekreasi anak (recreation), c) kemampuan untuk menetapkan aturan dan disiplin (discipline), d) kemampuan untuk memahami kondisi emosi anak (nurturance), dan e) kemampuan menjaga kesehatan fisik anak (health). Menurut Coleman \& Karraker (2000), terdapat beberapa faktor yang memengaruhi parenting self-efficacy, di antaranya pengalaman masa kecil orang tua, budaya dan komunitas setempat, pengalaman orang tua dengan anak-anak, dukungan sociomarital, tingkat kesiapan menjadi orang tua, dan karakteristik anak. Selain hal-hal tersebut, terdapat pula beberapa faktor demografis yang dapat memengaruhi parenting self-efficacy, yaitu usia ibu, latar belakang budaya (suku bangsa), pendidikan terakhir ibu, status pekerjaan ibu, status perkawinan ibu, pemasukan keluarga, dan usia anak (Coleman \& Karraker, 2000).

Dalam penelitian ini, karakteristik anak menjadi faktor yang paling disorot, di mana partisipan penelitian ini memiliki anak dengan ASD. Hal ini dikarenakan karakteristik yang ada pada anak ASD akan memengaruhi pola pengasuhan yang diterapkan orang tua. Karakteristik anak yang memengaruhi proses parenting adalah usia anak, kondisi mental anak, temperamen, dan kapabilitas fisik (Coleman \& Karraker, 2000; Vani, Raharjo, \& Hidayat, 2015). Menurut Kurniawan, Supraptiningsih, \& Hamdan (2018), terdapat beberapa prinsip yang harus dipegang oleh orang tua dalam mengasuh anak dengan ASD, di antara lain, a) pengawasan orang tua, b) kontrol dan konsistensi orang tua, c) keterlibatan orang tua, d) memahami perilaku anak, e) mengajarkan keterampilan sosial, dan f) mengembangkan kemampuan okupasi anak. Dengan bertambahnya usia anak dengan ASD, orang tua harus melakukan penyesuaian pada pola pengasuhan yang diberikan dan memahami perkembangan anak supaya anak tidak mengalami masalah yang berkepanjangan dalam perkembangannya (Setyaningsih, 2015).

Tugas pengasuhan yang dimiliki oleh ibu dari anak dengan ASD tentunya akan berbeda dari ibu yang memiliki anak normal. Tugas pengasuhan yang dimaksud, di antaranya tuntutan perawatan yang besar, kualitas hubungan antara anggota keluarga, kekhawatiran akan masa depan dan pendidikan, tenaga 
ekstra yang harus dikeluarkan, serta masalah keuangan (Raina et al., 2005). Hal ini yang membuat ibu harus memiliki parenting self-efficacy. Ibu yang memiliki parenting self-efficacy tinggi akan mampu memprediksi kebutuhan anak secara responsif, aktif menjalin interaksi langsung dengan anak dalam proses pengasuhan, tidak mempersepsikan masalah-masalah yang terjadi pada anak sebagai hal negatif, dan akan merasa yakin dalam menerapkan perilaku pengasuhan yang efektif untuk anak (Coleman \& Karraker, 2000; Hidayati \& Sawitri, 2018). Sementara itu, ibu yang memiliki parenting self-efficacy yang rendah akan memperlihatkan perilaku kontrol yang berlebihan, berfokus pada kesulitan anak, dan cenderung merasa kesulitan dalam menerapkan perilaku parenting yang efektif (Coleman \& Karraker, 2000; Hidayati \& Sawitri, 2018).

Beberapa penelitian sebelumnya menunjukkan bahwa terdapat inkonsistensi hasil parenting selfefficacy pada ibu yang memiliki anak dengan ASD. Lau et al. (2016) menemukan bahwa ibu yang memiliki anak dengan ASD memiliki parenting self-efficacy yang lebih rendah dibandingkan dengan ibu yang memiliki anak normal tanpa kebutuhan khusus. Sementara itu, penelitian yang dilakukan oleh Hidayati \& Sawitri (2018) menunjukkan bahwa sebagian besar responden penelitian tersebut, yang merupakan ibu yang memiliki anak dengan ASD, memiliki parenting self-efficacy yang tinggi. Parenting self-efficacy merupakan hal penting bagi orang tua yang memilliki anak dengan ASD karena menjadi prediktor yang kuat dalam performa parenting yang positif (Fajriyah, Qodariah, \& Moeliono, 2019; Hidayati \& Sawitri, 2018). Berdasarkan pemaparan diatas, maka dapat diketahui bahwa menjalankan peran sebagai ibu dari anak dengan ASD dapat memengaruhi keyakinan ibu terhadap kemampuannya dalam mengasuh anak. Perasaan yakin ini erat kaitannya dengan parenting self-efficacy, yang akan membantu ibu dalam menjalani masa pengasuhan.

\section{METODE}

Desain penelitian yang digunakan dalam penelitian ini adalah penelitian kuantitatif, di mana pengambilan data dilakukan sebanyak satu kali menggunakan self-report questionnaire dalam bentuk paper-based test. Penelitian ini bertujuan untuk melihat gambaran parenting self-efficacy pada ibu yang memiliki anak dengan ASD. Partisipan penelitian ini merupakan ibu yang memiliki anak dengan ASD yang berada di rentang usia 5-12 tahun. Pemilihan partisipan dilakukan dengan teknik purposive sampling, di mana peneliti bekerja sama dengan tiga klinik tumbuh kembang anak dan pusat terapi untuk mendapatkan informasi terkait partisipan penelitian potensial. Partisipan dalam penelitian ini berjumlah 34 orang ibu, yang memiliki anak dengan ASD berusia 5-12 tahun.

Gambaran parenting self-efficacy diperoleh dari pengambilan data menggunakan alat ukur SelfEfficacy for Parenting Task Index (SEPTI) yang dikembangkan oleh Coleman \& Karraker (2000), yang diadaptasi ke dalam Bahasa Indonesia oleh peneliti. Alat ukur ini terdiri dari 36 item yang terbagi ke dalam lima dimensi, yaitu achievement, recreation, discipline, nurturance, dan health. Alat ukur yang digunakan merupakan alat ukur hasil adaptasi di mana tahapan adaptasinya disesuaikan dengan alur adaptasi yang dijelaskan oleh Peters \& Passchier (2006). Setelah melalui proses adaptasi, dilakukan pula uji coba alat ukur kepada partisipan dan uji psikometrik.

Berdasarkan hasil uji coba alat ukur didapatkan nilai reliabilitas dan hasil validitas alat ukur. Nilai reliabilitas dari alat ukur SEPTI yang sudah diadaptasi yaitu sebesar 0,875 (reliabilitas sangat baik) sehingga alat ukur dinilai reliabel dan dapat digunakan. Untuk nilai validitas, berdasarkan expert judgment menggunakan content validity ratio, didapatkan bahwa 23 item dapat digunakan dan 13 item harus direvisi. Untuk nilai validitas berdasarkan uji confirmatory factor analysis, ditemukan bahwa alat ukur ini tergolong cukup valid dengan nilai RMSEA sebesar 0,043 dan nilai CFI sebesar 0,90.

Selain pengambilan data menggunakan alat ukur SEPTI yang sudah diadaptasi, setiap partisipan juga mendapatkan pertanyaan wawancara untuk menunjang data utama. Pertanyaan ini diperoleh dari hasil penurunan dari setiap dimensi parenting self-efficacy. Penilaian yang dilakukan pada data dari alat ukur SEPTI berupa data kuantitatif yang diperoleh dengan menjumlahkan seluruh jawaban partisipan dan membaginya dengan jumlah item. Sementara itu, pada bagian data tambahan, hasil yang diperoleh berupa data kualitatif yang akan dikoding berdasarkan kedekatan jawaban.

Setelah seluruh data dikumpulkan, dilakukan analisis data menggunakan statistik deskriptif untuk mendapatkan gambaran umum parenting self-efficacy dari subjek penelitian. Guna mendapatkan hasil lebih 
lanjut mengenai gambaran parenting self-efficacy, maka dilakukan uji Kolmogorov-Smirnov untuk melihat apakah data berdistribusi normal atau tidak. Setelah itu, dilakukan uji beda menggunakan uji independent one sample t-test untuk data yang berdistribusi normal dan hanya menggunakan satu variabel, sedangkan untuk data yang tidak berdistribusi normal akan dilakukan uji beda menggunakan uji Kruskal-Wallis. Pada penelitian ini, hasil gambaran parenting self-efficacy dijabarkan peneliti menggunakan kategorisasi skor, yaitu tinggi dan rendah.

\section{HASIL DAN PEMBAHASAN}

Partisipan yang mengikuti penelitian ini sebagian besar memiliki usia yang berada pada masa dewasa madya, yaitu sebanyak 20 partisipan (58,8\%). Mayoritas dari partisipan memiliki latar belakang suku Sunda (23 partisipan, 67,6 \%), masih tinggal bersama suami (27 partisipan, 79,4 \%), berpendidikan terakhir di jenjang S1 (14 partisipan, 41,2\%), seorang ibu rumah tangga atau tidak memiliki pekerjaan selain mengasuh anak (21 partisipan, 61,7\%) dan memiliki penghasilan keluarga sekitar Rp3.000.000Rp5.000.000 dalam satu bulan (12 partisipan, 35,2\%). Berdasarkan karakteristik anak, didapatkan bahwa mayoritas anak dari partisipan penelitian ini merupakan anak dengan usia 6 dan 8 tahun (masing-masing berjumlah 7 partisipan). Dalam hal urutan kelahiran anak, mayoritas anak partisipan merupakan anak pertama dari keluarga tersebut yaitu sebanyak 18 partisipan. Anak dari partisipan juga sebagian besar mendapatkan hasil diagnosis mengidap autism ketika anak berusia 2 tahun (19 partisipan).

Berdasarkan hasil penelitian, didapatkan bahwa sebagian besar partisipan (29 partisipan, 85\%) memiliki tingkat parenting self-efficacy yang tinggi. Hal ini menunjukkan bahwa sebagian besar ibu dari anak dengan ASD yang terlibat menjadi partisipan penelitian ini memiliki penilaian yang kuat terhadap kompetensi dirinya dalam menjalani peran sebagai orang tua dan menjalani tugas parenting. Hasil penelitian ini tidak sejalan dengan teori yang menyatakan bahwa ibu yang memiliki anak dengan ASD cenderung akan memiliki parenting self-efficacy yang rendah karena anak dengan ASD memiliki temperamen yang sulit dan memiliki gangguan perilaku yang dapat memengaruhi parenting self-efficacy ibu (Coleman \& Karraker, 2000; Lau, et al. 2016).

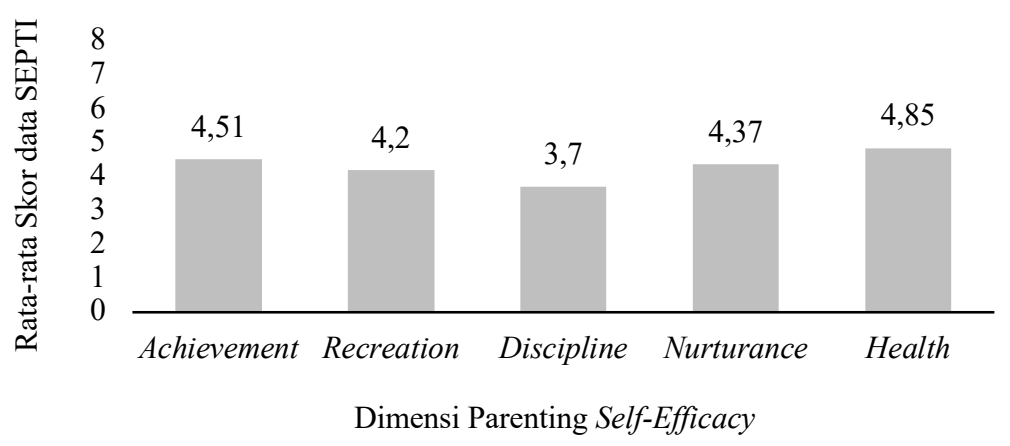

Figur 1. Perbandingan Rata-Rata Skor Tiap Dimensi Parenting Self-Efficacy (data SEPTI) Pada Partisipan Kategori Tinggi 


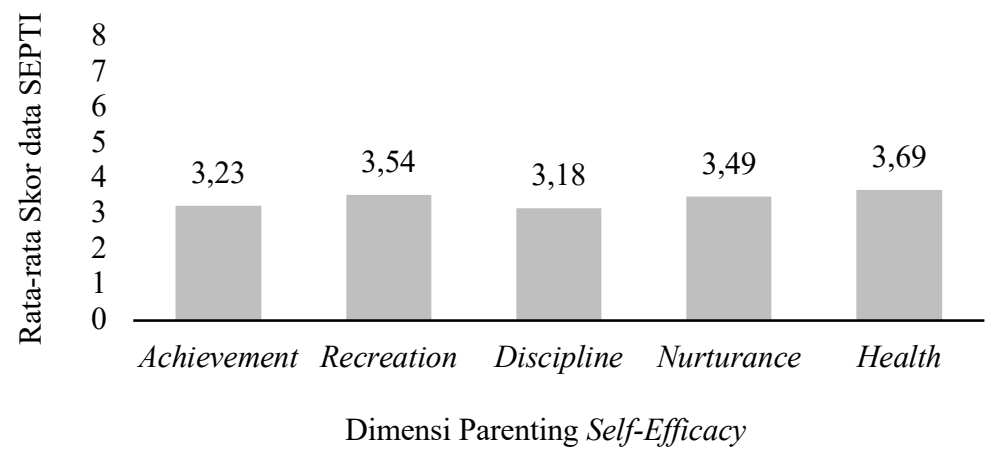

Figur 2. Perbandingan Rata-Rata Skor Tiap Dimensi Parenting Self-Efficacy (data SEPTI) Pada Partisipan Kategori Rendah

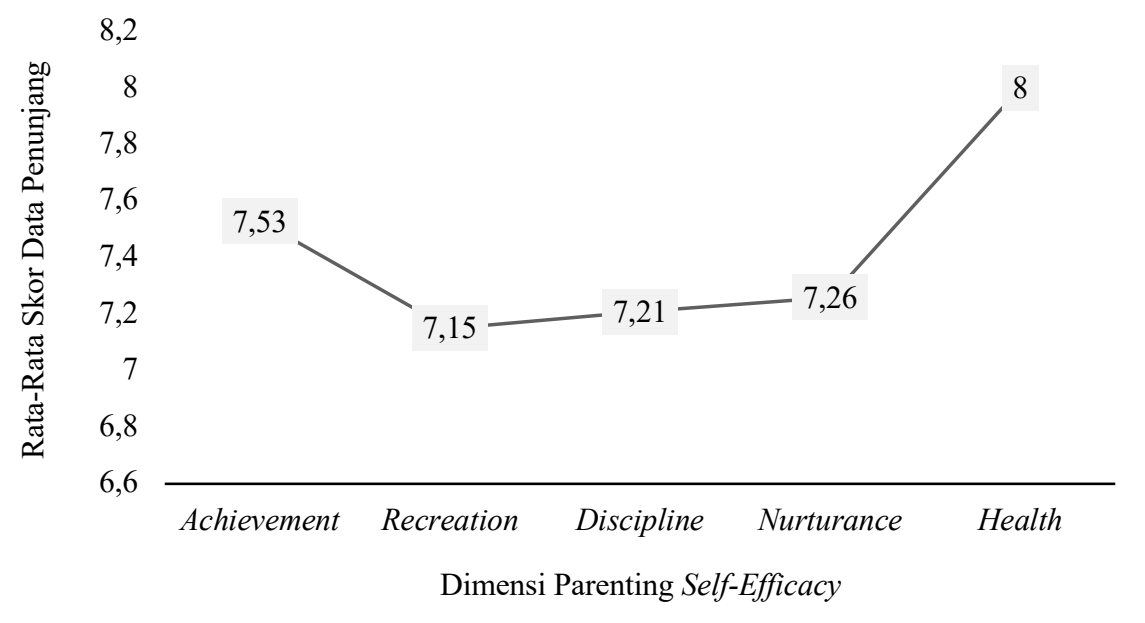

Figur 3. Perbandingan Rata-Rata Skor Data Penunjang Penilaian Subjektif Ibu terhadap Keyakinannya

Pada hasil penelitian, dijabarkan juga hasil rata-rata skor dari masing-masing dimensi parenting self-efficacy yang diperoleh partisipan yang memiliki parenting self-efficacy, baik dengan hasil tinggi ataupun rendah. Hasilnya dapat dilihat pada Figur 1 dan Figur 2, sedangkan untuk hasil data penunjang dapat dilihat pada Figur 3. Berdasarkan data pada Figur 1 dan Figur 2, dapat diketahui bahwa partisipan yang memiliki skor rata-rata parenting self-efficacy tinggi ataupun rendah tetap memiliki rata-rata skor yang paling tinggi pada dimensi menjaga kesehatan fisik anak (dimensi health). Dengan kata lain, partisipan memiliki penilaian yang kuat terhadap kemampuan mereka dalam menjaga kesehatan fisik anaknya. Rata-rata skor dimensi health ini juga didukung oleh data penunjang mengenai penilaian subjektif partisipan terhadap kemampuannya dalam menjalani tugas-tugas parenting. Berdasarkan data penunjang, didapatkan bahwa penilaian paling tinggi terdapat pada dimensi yang sama dengan hasil dari alat ukur, yaitu dimensi health. Ibu yang memiliki parenting self-efficacy tinggi akan memberikan pengasuhan yang berfokus pada anak, termasuk berfokus pada kesehatan fisik anak (Coleman \& Karraker, 2000). Dengan demikian, ibu akan merasa memiliki kompetensi untuk menjaga gizi anak, menyediakan nutrisi yang dibutuhkan anak, membantu anak menjalankan diet yang dikhususkan untuk anak dengan ASD, menjaga pola tidur anak, mengajak anak untuk berkegiatan di luar rumah, dan cepat tanggap ketika menyadari adanya suatu gejala penyakit pada anak. Hal-hal tersebut diperoleh dari pernyataan setiap partisipan dalam menjaga kesehatan fisik anak. Pemerolehan skor yang tinggi pada dimensi health ini diasumsikan terjadi karena sebagian besar partisipan memiliki banyak waktu dengan anak dan lebih terlibat dengan kegiatan anak sehari-hari, termasuk kegiatan pengobatan yang anak lakukan 
Hasil gambaran dimensi parenting self-efficacy lainnya juga memperlihatkan bahwa sebagian besar partisipan memiliki parenting self-efficacy yang rendah pada dimensi mengajarkan disiplin atau aturan pada anak (dimensi discipline). Hal ini menunjukkan bahwa penilaian ibu terhadap kemampuannya dalam mengajarkan disiplin atau aturan pada anak tidak terlalu kuat. Hal ini tidak sejalan dengan data penunjang mengenai penilaian subjektif partisipan terhadap kemampuannya dalam menjalani tugas-tugas parenting. Berdasarkan data penunjang, justru diketahui bahwa ibu menilai dirinya paling tidak mampu dalam membantu anaknya bersosialisasi (dimensi recreation). Ibu yang memiliki parenting self-efficacy rendah memiliki kecenderungan untuk berfokus pada kesulitan yang dimiliki anak, khususnya anak dengan ASD sehingga akan membuat ibu merasa tidak yakin bahwa dirinya mampu untuk mengajarkan disiplin dan aturan atau membantu anak dalam bersosialisasi (Coleman \& Karraker, 2000). Perolehan skor rendah pada dimensi discipline dan recreation ini diasumsikan terjadi akibat ibu merasa bahwa anak memiliki karakteristik yang menantang sehingga ibu menjadi merasa dirinya tidak memiliki kontrol atas perilaku anak (Coleman \& Karraker, 2000).

Dari hasil gambaran ketiga dimensi parenting self-efficacy lainnya ditemukan bahwa terdapat inkonsistensi dari partisipan yang berada pada kategori tinggi dan rendah (lihat Figur 1 dan Figur 2). Pada dimensi achievement, rata-rata skor yang didapatkan partisipan yang memiliki parenting self-efficacy tinggi berada pada posisi kedua, sedangkan pada partisipan yang memiliki parenting self-efficacy rendah berada pada posisi keempat. Perbedaan ini didukung oleh jawaban data penunjang terkait dimensi achievement, di mana pada partisipan yang memiliki parenting self-efficacy rendah, didapatkan bahwa partisipan masih merasa kurang optimal. Bahkan terdapat satu partisipan yang dengan jelas menyatakan bahwa dirinya memfasilitasi pencapaian anak di sekolah atau tempat terapi hanya pada bagian finansialnya saja. Hal ini terlihat jauh berbeda dengan partisipan yang memiliki parenting self-efficacy tinggi. Pada partisipan yang memiliki parenting self-efficacy tinggi, mereka memfasilitasi pencapaian anaknya dengan menyediakan setiap kebutuhan anak untuk bisa mengoptimalkan pembelajaran di sekolah atau di tempat terapi.

Pada dimensi nurturance, rata-rata skor yang didapatkan berada pada posisi ketiga, baik partisipan yang memiliki parenting self-efficacy tinggi ataupun rendah. Hal ini dapat terjadi diasumsikan karena baik pada partisipan yang memiliki parenting self-efficacy tinggi maupun rendah, keduanya memiliki kemampuan mengamati kondisi anak dengan baik. Pengamatan ini diperlukan oleh ibu yang memiliki anak dengan ASD, sebab beberapa anak dengan ASD tidak bisa menyampaikan emosinya dengan komunikasi verbal sehingga komunikasi muncul melalui bahasa tubuh. Pada dimensi recreation, rata-rata skor yang didapatkan partisipan yang memiliki parenting self-efficacy tinggi berada pada posisi keempat, sedangkan pada partisipan yang memiliki parenting self-efficacy rendah berada di posisi kedua. Perbedaan ini juga didukung oleh jawaban dari partisipan mengenai data penunjang dimensi recreation. Pada partisipan yang memiliki parenting self-efficacy tinggi, ibu memfasilitasi kebutuhan rekreasi anak dengan mengajak anak bermain di luar rumah dan terus mendampingi anak saat bersosialisasi dengan orang lain. Sementara itu, pada ibu yang memiliki parenting self-efficacy rendah, ibu memberikan anak kesempatan untuk bisa berbaur dengan anak lainnya tanpa diberikan pendampingan.

Berdasarkan hasil gambaran parenting self-efficacy terhadap data demografi dan faktor yang memengaruhi parenting self-efficacy beserta hasil uji beda yang dilakukan (lihat Tabel 1), didapatkan bahwa usia, suku bangsa, status perkawinan, pendidikan terakhir, status pekerjaan, penghasilan keluarga, usia anak, faktor pengalaman masa kecil orang tua, faktor budaya dan komunitas, dan faktor pengalaman dengan anak ternyata tidak memberikan perbedaan yang signifikan terhadap parenting self-efficacy ibu. Namun, jika dilihat berdasarkan rata-rata skor parenting self-efficacy yang diperoleh ibu, maka terdapat perbedaan yang muncul. Berikut penjelasan mengenai setiap perbedaan tersebut.

Tabel 1. Gambaran Parenting Self-Efficacy berdasarkan Data Demografi dan Faktor yang Memengaruhi

\begin{tabular}{llcccc}
\hline & Kategori & M & SD & p-value & Keterangan \\
\hline \multirow{2}{*}{ Usia Ibu (tahun) } & $31-39$ (dewasa muda) & 4,239 & 0,637 & 0,074 & $\mathrm{H}_{0}$ diterima \\
\hline \multirow{4}{*}{ Suku Bangsa } & $40-56$ (dewasa madya) & 4,126 & 0,414 & & \\
& Jawa & 4,214 & 0,497 & & \\
& Sunda & 4,090 & 0,476 & 0,406 & $\mathrm{H}_{0}$ diterima \\
& Minang & 5,270 &. & & \\
\hline Status Perkawinan & Batak & 4,343 & 0,599 & & \\
\hline
\end{tabular}




\begin{tabular}{|c|c|c|c|c|c|}
\hline & Ibu tunggal & 3,864 & 0,385 & & \\
\hline \multirow{4}{*}{ Pendidikan Terakhir } & SMA & 4,193 & 0,427 & \multirow{4}{*}{0,483} & \multirow{4}{*}{$\mathrm{H}_{0}$ diterima } \\
\hline & D3 & 4,086 & 0,472 & & \\
\hline & S1 & 4,274 & 0,597 & & \\
\hline & $\mathrm{S} 2$ & 3,750 & & & \\
\hline \multirow{2}{*}{ Status Pekerjaan Ibu } & Ibu rumah tangga & 4,283 & 0,550 & \multirow{2}{*}{0,278} & \multirow{2}{*}{$\mathrm{H}_{0}$ diterima } \\
\hline & Bekerja & 3,993 & 0,400 & & \\
\hline \multirow{5}{*}{ Penghasilan Keluarga } & $<\mathrm{Rp} 1.000 .000$ & 3,900 & 0,141 & \multirow{5}{*}{0,353} & \multirow{5}{*}{$\mathrm{H}_{0}$ diterima } \\
\hline & Rp1.000.000-Rp3.000.000 & 3,916 & 0,362 & & \\
\hline & Rp3.000.000-Rp5.000.000 & 4,112 & 0,388 & & \\
\hline & Rp5.000.000-Rp7.000.000 & 4,090 & 0,604 & & \\
\hline & $>\mathrm{Rp} 7.000 .000$ & 4,435 & 0,636 & & \\
\hline \multirow{8}{*}{ Usia Anak (tahun) } & 5 & 4,000 & 0,354 & \multirow{8}{*}{0,351} & \multirow{8}{*}{$\mathrm{H}_{0}$ diterima } \\
\hline & 6 & 4,483 & 0,340 & & \\
\hline & 7 & 4,363 & 0,930 & & \\
\hline & 8 & 4,236 & 0,748 & & \\
\hline & 9 & 4,095 & 0,219 & & \\
\hline & 10 & 3,850 & 0,294 & & \\
\hline & 11 & 3,847 & 0,300 & & \\
\hline & 12 & 4,154 & 0,329 & & \\
\hline \multirow{2}{*}{$\begin{array}{l}\text { Pengalaman Masa } \\
\text { Kecil Orang Tua }\end{array}$} & Menerapkan & 4,127 & 0,431 & \multirow{2}{*}{0,354} & \multirow{2}{*}{$\mathrm{H}_{0}$ diterima } \\
\hline & Tidak Menerapkan & 4,200 & 0,565 & & \\
\hline \multirow{2}{*}{ Budaya } & Menerapkan & 4,327 & 0,644 & \multirow{2}{*}{0,364} & \multirow{2}{*}{$\mathrm{H}_{0}$ diterima } \\
\hline & Tidak Menerapkan & 4,117 & 0,458 & & \\
\hline \multirow{2}{*}{ Komunitas } & Terlibat & 4,410 & 0,567 & \multirow{2}{*}{0,498} & \multirow{2}{*}{$\mathrm{H}_{0}$ diterima } \\
\hline & Tidak Terlibat & 4,044 & 0,440 & & \\
\hline \multirow{2}{*}{$\begin{array}{l}\text { Pengalaman Orang } \\
\text { Tua dengan Anak }\end{array}$} & Memiliki Pengalaman & 4,148 & 0,543 & \multirow[b]{2}{*}{0,598} & \multirow[b]{2}{*}{$\mathrm{H}_{0}$ diterima } \\
\hline & $\begin{array}{l}\text { Tidak Memiliki } \\
\text { Pengalaman }\end{array}$ & 4,225 & 0,459 & & \\
\hline
\end{tabular}

Berdasarkan data mengenai usia partisipan penelitian ini, didapatkan bahwa tidak terdapat perbedaan yang signifikan pada parenting self-efficacy. Tidak adanya perbedaan parenting self-efficacy ini diasumsikan terjadi karena seluruh partisipan berada di rentang usia yang dianggap sudah cukup matang dan sesuai tahapnya untuk memulai keluarga dan merawat anak (Rarastiti, 2014; Santrock, 2014). Namun, rata-rata skor parenting self-efficacy pada ibu yang berada di usia dewasa muda (31-39 tahun) lebih tinggi dibandingkan dengan ibu yang berada di usia dewasa madya (40-56 tahun). Hal ini dapat terjadi karena ibu yang berada di usia dewasa muda lebih mudah menerima instruksi atau pengajaran baru terkait hal pengasuhan anak dengan ASD (Rarastiti, 2014).

Hasil penelitian juga menunjukkan bahwa tidak terdapat perbedaan yang signifikan pada parenting self-efficacy berdasarkan latar belakang suku bangsa ibu, di mana ibu yang memiliki latar belakang budaya Minang memiliki rata-rata skor parenting self-efficacy paling tinggi dibandingkan dengan latar belakang suku bangsa yang lain. Hal ini dapat dikaitkan dengan faktor budaya yang dapat memengaruhi parenting self-efficacy dari ibu. Berdasarkan data tersebut, diketahui bahwa hanya sebagian kecil ibu yang menerapkan ajaran budaya sebagai dasar pengasuhannya pada anak dengan ASD, tetapi rata-rata skor parenting self-efficacy yang dimiliki justru lebih tinggi dibandingkan dengan ibu yang tidak menerapkan ajaran budaya. Hal ini diasumsikan terjadi karena ibu memiliki perasaan bertanggung jawab yang tinggi terhadap pengasuhan anaknya, sesuai dengan ajaran budaya yang ditanamkan di Indonesia (Valentia, Sani, \& Anggreany, 2017). Orang tua yang memiliki keyakinan dan perilaku mengenai pengasuhan yang sama dengan budaya cenderung memiliki parenting self-efficacy yang lebih tinggi (Coleman \& Karraker, 2000). Jika dilihat berdasarkan status perkawinan, didapatkan bahwa ibu yang tinggal bersama dengan suami saat mengasuh anak dengan ASD memiliki rata-rata skor parenting self-efficacy yang lebih tinggi dibandingkan dengan ibu yang sudah tidak tinggal bersama suami lagi. Namun, secara statistik ditemukan bahwa tidak terdapat perbedaan yang signifikan pada parenting self-efficacy ibu dari anak dengan ASD berdasarkan status perkawinan. Hal ini bisa saja terjadi karena berdasarkan data penunjang, diperoleh bahwa seluruh partisipan juga mendapatkan dukungan dari lingkungan sosialnya, seperti kakek, nenek, asisten rumah tangga, babysitter, dan lain-lain. Dengan adanya dukungan yang diperoleh ibu, baik itu dari suami maupun 
keluarga lainnya, ibu akan menjadi lebih "kuat" dalam menghadapi karakteristik anak dengan ASD karena ibu dapat mengandalkan lingkungannya (Rachmayanti \& Zulkaida, 2007).

Berdasarkan faktor pendidikan terakhir ibu, tidak terdapat perbedaan parenting self-efficacy yang signifikan. Namun jika dilihat berdasarkan rata-rata skor parenting self-efficacy, maka ibu yang mendapatkan pendidikan terakhir di jenjang S1 memiliki rata-rata skor parenting self-efficacy yang paling tinggi. Hal ini dikarenakan ibu yang memiliki pendidikan tinggi akan lebih mudah menerima informasi tentang cara pengasuhan anak dengan ASD yang baik (Rarastiti, 2014). Ibu dengan pendidikan tinggi akan memperoleh banyak informasi yang dapat dijadikan pedoman untuk membantu proses penyembuhan anak, salah satunya adalah informasi mengenai kebutuhan terapi anak dengan ASD untuk memaksimalkan perkembangan anak (Setyaningsih, 2015). Jika dilihat berdasarkan faktor pekerjaan ibu, hasil penelitian menunjukkan bahwa parenting self-efficacy ibu yang bekerja lebih rendah dibandingkan dengan ibu yang tidak bekerja. Hal ini dikarenakan pada ibu yang bekerja, ibu memiliki waktu yang lebih sedikit untuk dapat berinteraksi dengan anak sehingga ibu memerlukan pihak lain untuk menggantikan posisinya saat ibu bekerja (Rarastiti, 2014). Tidak adanya perbedaan yang signifikan terhadap parenting self-efficacy ibu berdasarkan faktor pekerjaan diasumsikan terjadi karena baik ibu yang bekerja ataupun tidak bekerja, keduanya mendapatkan dukungan dan bantuan dari lingkungan dalam hal mengasuh anak dengan ASD (lihat Tabel 1). Dengan adanya dukungan sosial pada ibu, ibu akan menilai pengasuhan yang diberikannya menjadi positif (Rachmawati \& Masykur, 2017).

Berdasarkan faktor penghasilan keluarga dalam satu bulan, diketahui bahwa ibu yang memiliki penghasilan keluarga lebih besar dari Rp7.000.000 dalam satu bulan memiliki rata-rata skor parenting selfefficacy yang paling tinggi di antara rata-rata penghasilan keluarga lainnya. Hal ini sejalan dengan hasil penelitian Rachmayanti \& Zulkaida (2007), di mana ibu yang memiliki kemampuan finansial yang lebih baik memiliki kesempatan yang lebih besar untuk memberikan beberapa terapi sekaligus untuk anak sehingga anak bisa menjalani proses "penyembuhan" yang lebih cepat. Hal ini diasumsikan dapat membuat parenting self-efficacy ibu menjadi lebih tinggi.

Berdasarkan faktor demografi yang terakhir, yaitu usia anak, hasil penelitian menunjukkan bahwa tidak terdapat perbedaan parenting self-efficacy yang signifikan pada ibu yang memiliki anak dengan ASD berusia 5, 6, 7, 8, 9, 10,11, atau bahkan 12 tahun. Hal ini diasumsikan terjadi karena adanya kesamaan pada karakteristik anak dengan ASD berusia 5-12 tahun sehingga kesulitan-kesulitan pengasuhan yang dirasakan partisipan juga kurang lebih sama. Selain itu, pada usia 5-12 tahun, anak dengan ASD juga sedang berada di tahap perkembangan yang sama sehingga setiap ibu harus memenuhi tugas perkembangan yang sama pula (Desiningrum, 2016; Desmita, 2006; Santrock, 2014).

Berdasarkan data penunjang mengenai faktor-faktor yang memengaruhi tingkat parenting selfefficacy ibu, maka terdapat beberapa temuan lain yang mendukung tingginya tingkat parenting self-efficacy partisipan penelitian ini. Hasil penelitian menunjukkan bahwa sebagian besar partisipan tidak menerapkan pengalaman masa kecil mereka dalam pengasuhannya saat ini. Hal ini terjadi karena adanya perbedaan pada kondisi anak dengan ASD sehingga kebutuhan yang harus dipenuhi pun menjadi berbeda. Selain itu, keterlibatan ibu dalam suatu komunitas orang tua anak dengan ASD membuat rata-rata skor parenting selfefficacy ibu menjadi lebih tinggi dibandingkan ibu yang tidak terlibat. Komunitas ini memberikan banyak dukungan bagi ibu dalam mengasuh anak dengan ASD, salah satunya adalah pemberian informasi terkait dengan autism sehingga pengasuhan pun dapat berjalan dengan lebih maksimal. Menurut Coleman \& Karraker (2000), dukungan yang didapatkan ibu dari komunitas membuat ibu memiliki keyakinan dan perilaku yang sesuai dengan komunitasnya sehingga parenting self-efficacy ibu pun menjadi lebih tinggi. Dengan melakukan pengamatan terhadap ibu lain dalam pengasuhan anak dengan ASD, maka hal tersebut dapat mengembangkan parenting self-efficacy ibu yang melihatnya (Coleman \& Karraker, 2000).

Temuan lain yang didapatkan adalah partisipan yang memiliki pengalaman bersama anak-anak sebelumnya justru memiliki parenting self-efficacy yang lebih rendah dibandingkan dengan partisipan yang tidak memiliki pengalaman dengan anak-anak. Hal ini diasumsikan terjadi akibat pengalaman bersama anak-anak tersebut tidak memengaruhi pengasuhan yang diberikan, mengingat karakteristik anak dalam penelitian ini adalah anak dengan ASD Oleh sebab itu, pengalaman dengan anak normal belum tentu bisa dijadikan suatu pembelajaran dalam mengasuh anak dengan ASD. Padahal, pengalaman langsung terkait suatu perilaku tertentu merupakan sumber informasi yang kuat dalam pembentukan efficacy seseorang (Coleman \& Karraker, 2000). Hasil penelitian juga menunjukkan bahwa seluruh partisipan mendapatkan kesulitan dalam proses pengasuhan yang berasal dari karakteristik anak. Kesulitan-kesulitan yang dirasakan 
ini dapat memengaruhi parenting self-efficacy ibu. Ketika ibu menganggap anak mereka terlalu emosional dan sulit untuk bersosialisasi, maka parenting self-efficacy yang dimiliki ibu pun menjadi lebih rendah (Coleman \& Karraker, 2000).

\section{SIMPULAN}

Berdasarkan hasil yang didapatkan dari penelitian mengenai gambaran parenting self-efficacy pada ibu yang memiliki anak dengan ASD pada 34 partisipan, maka didapatkan kesimpulan sebagai berikut:

1. Ibu yang memiliki anak dengan ASD, khususnya anak dengan usia 5-12 tahun, yang menjadi partisipan penelitian ini, memiliki tingkat parenting self-efficacy yang tinggi. Hal ini menunjukkan bahwa ibu yang memiliki anak dengan ASD berusia 5-12 tahun memiliki perilaku pengasuhan yang positif dan mampu menyiapkan lingkungannya menjadi lingkungan yang adaptif, menstimulasi, sehat, menyenangkan, dan terlibat secara penuh dalam menjalankan perannya sebagai orang tua.

2. Ibu yang memiliki anak dengan ASD berusia 5-12 tahun memiliki tingkat keyakinan diri atas kemampuannya dalam menjaga kesehatan fisik anak (dimensi health) yang paling tinggi di antara keempat dimensi lainnya. Hal ini menunjukkan bahwa ibu memiliki keyakinan yang tinggi terhadap kemampuannya dalam menjaga kesehatan fisik anak.

3. Ibu yang memiliki anak dengan ASD berusia 5-12 tahun memiliki tingkat keyakinan diri atas kemampuannya dalam menetapkan aturan dan disiplin pada anak (dimensi discipline) yang paling rendah di antara keempat dimensi lainnya. Hal ini menunjukkan bahwa ibu memiliki keyakinan yang rendah terhadap kemampuannya dalam menetapkan aturan dan disiplin pada anak.

4. Usia ibu, suku bangsa ibu, pendidikan terakhir ibu, status pekerjaan ibu, status perkawinan ibu, penghasilan keluarga, dan usia anak tidak memberikan perbedaan signifikan pada tingkat parenting self-efficacy ibu yang memiliki anak dengan ASD berusia 5-12 tahun.

5. Ibu dari anak dengan ASD yang menerapkan aturan budaya dan terlibat dalam komunitas orang tua anak dengan ASD memiliki parenting self-efficacy yang lebih tinggi dibandingkan dengan ibu yang tidak menerapkan aturan budaya dan tidak terlibat dalam komunitas.

6. Ibu dari anak dengan ASD yang tidak menerapkan pengalaman masa kecil orang tua dan tidak memiliki pengalaman dengan anak-anak memiliki parenting self-efficacy yang lebih tinggi dibandingkan ibu yang menerapkan pengalaman masa kecil dan memiliki pengalaman dengan anak-anak.

Adapun saran-saran yang dapat dilakukan untuk perkembangan penelitian lebih lanjut akan dijelaskan sebagai berikut,

1. Berdasarkan hasil penelitian, didapatkan bahwa ibu yang memiliki anak dengan ASD dan terlibat dalam komunitas autism memiliki tingkat parenting self-efficacy yang lebih tinggi dibandingkan dengan ibu yang tidak terlibat. Hal ini diasumsikan dapat terjadi karena adanya tambahan support yang diterima oleh ibu. Namun, perlu dilakukan penelitian lebih lanjut mengenai peranan social support, khususnya dari komunitas, terhadap tingkat parenting selfefficacy.

2. Penerimaan diri ibu terhadap kondisi anak diasumsikan dapat memengaruhi tingkat parenting self-efficacy ibu yang memiliki anak dengan ASD. Namun, masih diperlukan penelitian lebih lanjut mengenai peranan penerimaan diri terhadap parenting self-efficacy ibu karena pada penelitian ini penerimaan diri tidak diteliti lebih lanjut.

3. Dukungan yang diberikan oleh suami kepada ibu juga diasumsikan dapat memengaruhi tingkat parenting self-efficacy ibu yang memiliki anak dengan ASD. Namun, perlu dilakukan penelitian lebih lanjut mengenai peranan social support, khususnya dari pasangan, terhadap tingkat parenting self-efficacy.

4. Dalam penelitian tidak dilakukan pemilihan sampel berdasarkan tingkat severity ASD pada anak sehingga diperlukan eksplorasi lebih lanjut terkait tingkat severity anak dengan ASD agar dapat menjelaskan dinamika parenting self-efficacy lebih lanjut. 


\section{DAFTAR PUSTAKA}

American Psychiatric Association. (2013). Diagnostic and statistical manual of mental disorders (5th ed.). United States.

Coleman, P. K., \& Karraker, K. H. (2000). Parenting self-efficacy among mothers of school-age children: Conceptualization, measurement, and correlates. Family Relations: An Interdisciplinary Journal of Applied Family Studies, 49(1), 13-24.

Coleman, P., \& Karraker, K. (1998). Self-efficacy and parenting quality: Findings and future applications. Developmental Review, 18(1), 47-85.

Desiningrum, D. R. (2016). Psikologi anak berkebutuhan khusus. Yogyakarta: Psikosain.

Desmita. (2006). Psikologi perkembangan. Bandung: PT Remaja Rosdakarya.

Fajriyah, N., Qodariah, L., \& Moeliono, M. F. (2019). Komparasi parenting self-efficacy pada ibu usia remaja dan dewasa di Kecamatan Banjarharjo Brebes. Journal of Psychological Science and Profession, 3(1), 12-20.

Ghoniyah, Z., \& Savira, S. I. (2015). Gambaran psychological well being pada perempuan yang memiliki anak Down syndrome. Character: Jurnal Penelitian Psikologi, 3(3), 1-8.

Hidayati, Z. K., \& Sawitri, D. R. (2018). Hubungan antara dukungan sosial dengan maternal self-efficacy pada anak autism spectrum disorder (ASD). Jurnal EMPATI, 6(2), 10-14.

Indrasari, S. Y., \& Affiani, L. (2018). Peran persepsi keterlibatan orang-tua dan strategi pengasuhan terhadap parenting self-efficacy. Jurnal Psikologi Sosial, 16(2), 74-85.

Kurniawan, A. S., Supraptiningsih, E., \& Hamdan, S. R. (2018). Pengasuhan pada anak autis: Telaah pada ibu dengan anak autis. Prosiding Nasional Psikologi, 2.

Lau, W. Y. P., Peterson, C. C., Attwood, T., Garnett, M. S., \& Kelly, A. B. (2016). Parents on the autism continuum: Links with parenting efficacy. Research in Autism Spectrum Disorders, 26, 57-64.

Listiyaningsih, R., \& Dewayani, T. N. E. (2009). Kepercayaan diri pada orangtua yang memiliki anak tunagrahita. Fakultas Psikologi Universitas Mercu Buana, Yogyakarta.

National Institute of Mental Health. (2016). Autism spectrum disorder. Retrieved from https://www.nimh.nih.gov/health/topics/autism-spectrum-disorders-asd/index.shtml

Peters, M., \& Passchier, J. (2006). Translating instruments for cross-cultural studies in headache research. Headache: The Journal of Head and Face Pain, 46(1), 82-91.

Priyatna, A. (2010). Amazing autism: Memahami, mengasuh, dan mendidik anak autis. Jakarta: PT Elex Media Komputindo.

Rachmawati, S. N., \& Masykur, A. M. (2017). Pengalaman ibu yang memiliki anak Down syndrome. Jurnal EMPATI, 5(4), 822-830.

Rachmayanti, S., \& Zulkaida, A. (2007). Penerimaan diri orangtua terhadap anak autisme dan peranannya dalam terapi autisme. Jurnal Psikologi, 1(1), 7-17.

Raina, P., O’Donnell, M., Rosenbaum, P., Brehaut, J., Walter, S. D., Russell, D. \& Wood, E. (2005). The health and well-being of caregivers of children with cerebral palsy. Pediatrics, 115(6), e626-e636.

Rarastiti, C. N., \& Syauqy, A. (2014). Hubungan karakteristik ibu, frekuensi anak ke posyandu, asupan energi dan protein dengan status gizi anak usia 1-2 tahun. Journal of Nutrition College, 3(1), 98-105.

Santrock, J. W. (2014). A topical approach to life-span development (7th ed.). New York: McGraw-Hill Education.

Setyaningsih, W. (2015). Hubungan pola asuh orang tua dengan perkembangan sosial anak autisme di SLBlb Harmoni Surakarta. Jurnal Kesehatan, 6(2), 123-129.

Valentia, S., Sani, R., \& Anggreany, Y. (2017). Hubungan antara resiliensi dan penerimaan orangtua pada ibu dari anak yang terdiagnosis autism spectrum disorder (ASD). Jurnal Psikologi Ulayat, 4(1), 4358.

Vani, G. C., Raharjo, S. T., \& Hidayat, E. N. (2015). Pengasuhan (good parenting) bagi anak dengan disabilitas. Prosiding Penelitian dan Pengabdian kepada Masyarakat, 2(1), 96-102.

Widiastuti, D. (2014). Perilaku anak berkebutuhan khusus gangguan autisme di SLB Negeri Semarang tahun 2014. BELIA: Early Childhood Education Papers, 3(2), 72-78. 